\title{
Value chain deconstruction in the United Kingdom retail life insurance industry and resulting strategic options for new entrants to the market
}

\author{
W.R. Dommisse and H. Oosthuizen* \\ Graduate School of Business, University of Stellenbosch, \\ PO Box 610, Bellville 7535, Republic of South Africa \\ ho2@usb.sun.ac.za
}

Received August 2004

\begin{abstract}
Porter coined the term 'value chain' in 1985. Since then the concept has found general acceptance within the strategic planning realm. In order to explain changes occurring in industries affected by increased volatility, a thesis of the deconstruction of the value chain is gaining acceptance. This concept is investigated by means of a literature review. The theory is then tested in the turbulent United Kingdom (UK) retail life insurance industry to see if an application can be found. This industry is briefly analysed and the main environmental factors affecting it are investigated. These are a $£ 27$ billion per annum savings gap, under-performing equity markets, regulatory influences of depolarisation, stakeholder's pensions and technological developments mainly as a result of the Internet. The conclusion reached is that the changes are creating at least partial deconstruction. Within this framework the strategic options for new entrants into the UK retail life insurance market are explored.
\end{abstract}

This paper is based upon a research project by Robert Dommisse, Value chain deconstruction in the United Kingdom Life and Pensions Industry and resulting strategic options for Sanlam, submitted in 2003 to the University of Stellenbosch Business School in partial fulfilment for the MBA degree. It was awarded a distinction.

*To whom all correspondence should be addressed.

\section{Introduction}

Since Porter coined the phrase 'value chain' in 1985 (Porter, 1985:33) the world has experienced major change. With the rapid development and introduction of more advanced communication and computer technology in the latter part of the 1990s, industry models have changed. This gave rise to concepts such as the 'new economy' which suggested old rules and strategies were invalid.

In trying to explain these changes in industry, a thesis that appears to be gaining broader acceptance is that of the 'deconstruction of the value chain'. The thinking is that whole industries may be reorganising and reconstructing and that companies need to adopt strategies around this in order to survive and prosper.

This paper investigates the concept of the deconstruction of the value chain and explores the benefit it can add in strategy formulation by applying it to an industry that is deemed to be undergoing rapid change. For this purpose the retail life insurance business in the United Kingdom (UK) has been selected. Strategic options for a new entrant into the market are discussed.

\section{Structure of the paper and research methodology}

The paper briefly discusses the value chain. A literature review of deconstruction of the value chain follows. The retail life insurance industry in the UK is defined, its products listed and an industry value chain constructed. The external factors impacting on the UK retail life insurance value chain are discussed with specific reference to the impact on each major component of the value chain. A conclusion is drawn as to whether the chain is showing signs of deconstruction. The strategic options for new entrants in each part of the deconstructed chain are investigated.

The main methodology used was a literature review of published works and research conducted by consulting companies. Discussions with senior managers of a major South African life insurer, who are currently working in the UK market or with previous exposure to this market, were used to augment and verify the understanding of the literature study.

\section{The value chain concept}

In 'Competitive Strategy' Porter (1980:39) defined the three generic strategies of overall cost leadership, differentiation and focus. In 'Competitive Advantage' (1985:33) he builds on these and shows how the organisation can achieve competitiveness by choosing its scope and the range of activities that it undertakes. In doing this he coined the term 'value chain'.

The industry within which companies operate is termed the ‘value system' (Porter, 1985:35). The value system is thus 
the combination of the value chains of companies comprising an industry.

It appears that the term 'value system' has not found the general acceptance of the 'value chain'. Later authors such as Evans and Wurster (1997:72) and Thompson and Stricland (2001:129) use the term 'industry value chain' when they refer to what Porter defined as the 'value system'.

\section{Theory of value chain deconstruction}

As analysts, mainly in the management consulting arena, observed changes in industries resulting from, amongst other, the introduction of new technology and regulatory amendments, they noticed a phenomena where parts of the traditional industry value chain started breaking away and either forming new industries or combining with parts of different industries (Bresser, Heuskel \& Nixon, 2000:1). This break up was given the label of 'deconstruction'.

Observing deconstruction alone, however, adds little to company strategy. In order to use deconstruction to gain strategic benefit, one must understand the reasons for deconstruction, which parts of the chain are most likely to be affected and how it can be used by the company to its advantage.

The main theories relating to the reasons for value chain deconstruction of 'rich versus reach', 'interaction versus transformation' and 'three businesses in one' are investigated.

\section{Rich versus reach}

Evans and Wurster (1997:72) hold that the value chain has traditionally been defined in terms of the trade off between 'richness' and 'reach' of information. Companies, for example, set up branch networks to communicate 'rich' (read detailed or complex) information to customers, whilst advertising could 'reach' a broader population, but not deliver rich information effectively.

The authors hold that a company can increase its competitiveness in this situation by moving along the tradeoff line, e.g. offering higher reach but with less richness than a competitor. A second, but more difficult, strategy would be to move the line outward by offering both increased richness and reach.

Evans and Wurster (2000b:35) predict that the trade-off line is not only shifted by innovative competitors. Two inventions are causing the line to move. The first is the advent of open, universal communication standards, such as found in Internet communication. The second is the introduction of content standards for the definition, storage and presentation of information.

The effect of these changes is that rich information will increasingly reach a much larger audience at a greatly reduced cost. In addition, the market starts performing activities previously requiring managerial co-ordination. Due to this some parts of the value chain might become obsolete and others can be performed in new ways. The outcome is often that the traditional integrated value chain starts deconstructing.

\section{Interaction versus transformation}

Butler and Hall (1997:4) maintain that organisations consistently balance interaction cost with transformation cost. Interaction is defined as 'the searching, coordinating and monitoring that firms do when they exchange goods, services or ideas'. Transformation is not as clearly defined but relates to the economic activities of production and delivery (Butler \& Hall, 1997:2).

The theory of comparative advantage (Carbaugh, 2002:29) holds that the parties should trade and increase individual and total wealth when one party has a comparative advantage in an activity. Butler and Hall (1997:4) introduce interaction cost as a further dimension. They hold that even if one party has a comparative advantage, but the cost of finding, negotiating and exchanging goods is more than can be gained through trading, the parties would not trade.

Interaction is estimated to represent as much as 51 percent of labour activity in the United States of America (USA) with an equivalent cost of one third of the gross domestic product (Butler \& Hall, 1997:). The authors (Butler \& Hall, 1997:4) postulate that due to this huge cost, traditional organisations were constructed to decrease the impact of interaction.

It follows logically that should, for any reason, the cost of interaction decrease, the dynamics of industry could change. A decrease in interaction cost could, for example, lead to a component being sourced from a third party rather than manufactured in-house.

\section{Three different businesses}

The 'three firms in one' theory presents one of the most attractive models. This probably results from the instinctive recognition of the different dimensions of an organisation that managers have noticed through experience but were unable to describe in terms of a theoretical framework.

Hagel and Singer (1999a:133) suggest that most organisations engage in three kinds of businesses. The first attracts customers; the second develops products, whilst the third oversees operations. Each unit employs different types of people, has different cultures and even has different economic and competitive imperatives. The main driver for the customer business is scope (gaining the largest share of customer wallet), whilst operations focus on scale. The product unit focuses on speed to market and innovation.

In 'Blown to Bits' Evans and Wurster (2000a:210) follow a similar approach by holding that the integrated value chains often found in industries are sub-optimal because they integrate businesses with different drivers into one.

Hagel and Singer (1999b:213) agree that the trade-offs resulting from running the businesses as one adds inefficiency to the system. As soon as the cost of these 
inefficiencies is more than the interaction cost holding the business together, organisations will unbundle into three.

The unbundled businesses are not predicted to necessarily remain loose standing entities. Some parts are expected to consolidate with similar sections of other organisations that have also unbundled. Consolidation in the customer and operations businesses is likely as the business drivers are scope and scale. Product companies are foreseen to remain small with fragmented players characterising the new industry.

Evans and Wurster (2000a:10) argue that in the traditional value chain trade-offs were inevitable. One activity was done at a sub-optimal level to accommodate another. This resulted in some activities cross-subsidising others. The player with the lowest average cost for all activities held a competitive advantage.

With deconstruction, ‘de-averaging' (Evans, 1998:1) occurs. Each part of the value chain must now be competitive. 'Deconstrutors' seek out the most profitable part of the chain and focus only on this element, thus gaining a competitive advantage. Traditional players are potentially left with the less profitable activities.

\section{How does deconstruction start?}

Prima facie the three models described present three different solutions to the same problem. Further analysis concludes that they are closely linked. The 'three firms in one' appears to present the basic theory, with 'richness and reach' and 'interaction versus transformation' explaining why the 'three firms in one' will deconstruct.

The most probable catalyst of deconstruction in an industry is a new competitor entering. These competitors usually choose the highly profitable parts of the value chain and exploit averaging by offering the consumer a new value proposition.

The second source of change is current competitors. Successful organisations often refuse to change unless a threat makes it necessary. Hagel and Singer (1999b:227) hold that organisations operating in markets that experience major technological or regulatory discontinuities are likely to change and unbundle because management feels highly threatened and thus forced into drastic actions.

The dominant role of management consultants in modern industry cannot be underestimated. When dealing with their predictions about future trends in an industry one often contemplates whether the forecast is accurate or if the predictions and consulting around these predictions in fact shape the future. Finding an answer falls outside the scope of this paper. Suffice to say that when most consulting firms follow a similar approach it will likely become industry practice.

\section{Summary}

There appears to be three different theories of why deconstruction in the value chain occurs, namely the disappearance of the 'rich versus reach' and 'transformation versus interaction' trade-offs and the 'three businesses in one' argument. The latter is held to be the dominant model with the other two explaining why the three businesses deconstruct.

\section{United Kingdom retail life insurance industry}

With annual premiums of $£ 93$ billion (Association of British Insurers, 2003a:3), the UK life insurance market is the largest in Europe and the third largest in the world in terms of both absolute size and per capita insurance expenditure. Premium income as a percentage of gross domestic product is the second highest in the world (Association of British Insurers, 2003a:6).

The savings industry has assets under management of more than £2 000 billion (Fund Managers’ Association, 2001: 6). Life insurance, which has a retail and wholesale component, represents assets under management of $£ 840$ billion (Fund Managers' Association, 2001:6). Of this $£ 600$ billion is estimated to represent the retail sector (Association of British Insurers, 2003a:7).

In 2001, 91 percent (Association of British Insurers, 2003b:1) of long-term insurance premiums (including retail and wholesale) were attributed to 20 insurers. The rest of the market contains almost 200 smaller companies. Table 1 gives a breakdown of the top 20 competitors.

\section{Table 1: 2001 top 20 insurers}

\begin{tabular}{l|l|c|c}
\hline Rank & \multicolumn{1}{|c|}{ Company } & $\begin{array}{c}\text { Premium } \\
\text { income } \\
\mathbf{E} \mathbf{m}\end{array}$ & $\begin{array}{c}\text { Market } \\
\text { share } \\
\mathbf{\%}\end{array}$ \\
\hline 1 & Halifax & 9077 & 9,8 \\
\hline 2 & CGNU (renamed Aviva in 2002) & 8727 & 9,4 \\
\hline 3 & Barclays & 8424 & 9,1 \\
\hline 4 & Prudential & 8122 & 8,7 \\
\hline 5 & Standard Life & 7678 & 8,3 \\
\hline 6 & Lloyds TBS & 5016 & 5,4 \\
\hline 7 & Legal \& General & 4404 & 4,7 \\
\hline 8 & AXA & 3938 & 4,2 \\
\hline 9 & AEGON & 3609 & 3,9 \\
\hline 10 & Zurich Financial Services & 3358 & 3,6 \\
\hline 11 & Abbey National & 3291 & 3,5 \\
\hline 12 & American Life & 2910 & 3,1 \\
\hline 13 & National Westminster Life & 2716 & 2,9 \\
\hline 14 & Friends Provident & 2646 & 2,9 \\
\hline 15 & Morgan Grenfell & 2282 & 2,5 \\
\hline 16 & AMP & 2051 & 2,2 \\
\hline 17 & Phillips \& Drew & 1873 & 2,0 \\
\hline 18 & Royal \& SunAlliance & 1751 & 1,9 \\
\hline 19 & Royal London & 1667 & 1,8 \\
\hline 20 & Skandia & $\mathbf{8 4 ~ 8 9 2}$ & $\mathbf{9 1 , 3}$ \\
\hline- & Total Top 20 & $\mathbf{9 3 ~ 0 0 0}$ & $\mathbf{1 0 0 , 0}$ \\
\hline- & Total Market & &
\end{tabular}

Source: Association of British Insurers, 2003b:1.

To test the level of concentration in the market the Herfindahl-Hirschman Index (US Department of Justice, 2003:1) was used. The index is calculated by squaring the market share of each firm and adding the results. Markets in which the Herfindahl-Hirschman Index is between 1000 and 1800 are considered moderately concentrated. An index higher than 1800 indicates a concentrated market. 
Applying the formula to Table 1 results in an answer of 646, indicating a market that is not concentrated. Further consolidation in the industry is thus probable.

\section{Retail life insurance products and value chain}

\section{Products}

Retail life insurance companies provide two main product categories, namely risk cover and savings policies. The two products are often packaged in one insurance policy.

A pure life risk policy is a contract in which the insurer guarantees to pay the beneficiary an amount should the insured die within the predetermined period (Diacon \& Carter, 1992:40). The life premium is calculated based on the life expectancy of the insured. By pooling individuals, insurers can offset losses on those who die earlier than expected against profits made on those who live longer than expected.

The aim of a savings policy is to accumulate an underlying value, which is available for the policyholder at a date in the future (Diacon \& Carter, 1992:40). The policy may also pay out if it is cancelled or on the death of the policyholder. Saving products consist mainly of with-profit, unit linked and annuity policies.

\section{Value chain}

The products described are delivered to the market through a number of discrete activities which, when combined, form the company value chain. Marlborough Stirling (2001: 2) divides the life insurance value chain into the following activities: sales, underwriting, policy issue, customer interaction (e.g. call centres), claims, processing of policy records, accounting, capital, product development and the statutory actuary role. Taylor, Seah, Cannon and Stone (2002:351) illustrate the roles in the life insurance value chain by referring to three main categories of manufacturing, distribution and retail.

In Figure 1 the respective strengths of these models were used and combined into one simple model that illustrates the five major areas of the value chain.

Distribution focuses on understanding the client's needs and distributing a product that meets these. The product is designed and packaged by the next unit. Risk management is closely intertwined with the insurance product as the actuary determines rates for risk products and bonuses declared on with-profit products. Asset management entails the selection and management of investment instruments purchased by cash inflows generated from the sale of products. Operations cover the infrastructure, information technology and administration processes needed to deliver the other services in the chain.

\section{Factors impacting on the value chain}

Deconstruction theory holds that rapid changes in an industry can ultimately result in the traditional value chain disintegrating. These rapid changes can originate from external sources, i.e. from areas such as the political, economic, social or technological environment (Thompson \& Strickland, 2001:73). Alternatively, factors from within the industry or from another industry can create this discontinuance.

\section{The savings gap}

European countries have traditionally provided better social welfare than the USA or Japan. With an ageing population, these benefits are becoming costly and governments will increasingly have to find ways whereby individuals are held responsible for their own retirement savings.

In 2002 Oliver Wyman \& Company (2002:2) produced a report on savings levels in the UK. The firm calculated that the UK market has a savings gap of £27 billion per annum between what is needed for retirement and current saving levels. This represents almost 30 percent of the life insurance sector's annual premium income.

\section{Equity markets}

Equity markets around the world have been volatile for a number of years. In the UK a similar trend has been observed. Investors in the equity market have often seen their wealth decrease rapidly. Political instability in the Middle East is likely to perpetuate this volatility.

\section{Stakeholder pensions}

Stakeholder pensions represent one method by which government has attempted to fill the savings gap. They are mainly sold and administered by insurance companies.

One of the requirements for a stakeholder product laid down by government is that the total administration charges may not exceed one percent of assets per annum (Self, 2002:1). This has led to the term 'the one percent world'. The prediction is made that there will be increased pressure on providers of other products to decrease charges to this level.

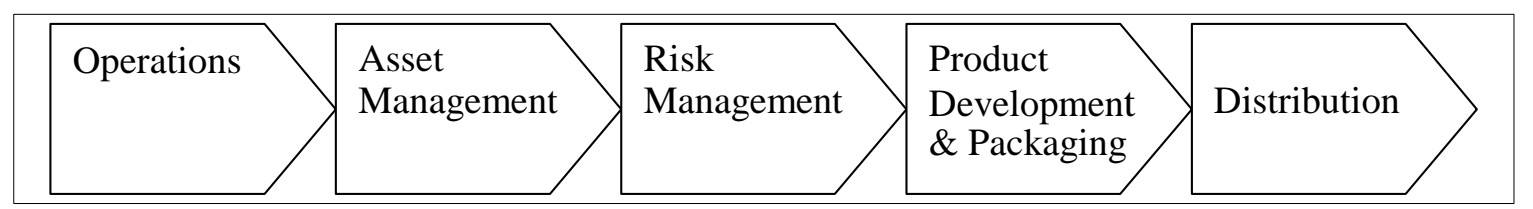

Figure 1: combined value chain model 
The 'one percent world' was enhanced by the introduction of 'CAT standards' by the Financial Services Authority. CAT is an abbreviation for fair Charges, easy Access and decent Terms (Financial Services Authority, 2003:1).

\section{Sandler report}

Due to the concern over the levels of savings in the UK market the Treasury tasked Ron Sandler to investigate the medium and long-term retail savings industry.

The Sandler report was released in July 2002. The main recommendations (Ernst \& Young, 2002:1) include:

- A split between 'with advice' and 'without advice' products, with the former sold without commission (i.e. advice is fee based instead of commission driven).

- The term 'independent advisor' being reserved for people selling fees based products.

\section{Polarisation and depolarisation}

The Financial Services Act of 1986 introduced the concept of polarisation. This regime divided firms selling insurance products into two groups, Independent Financial Advisors (IFA's) and representatives of insurance companies (Financial Services Authority, 2002b: 11). Representatives were only allowed to sell a single company's products, whilst an IFA had to recommend the most suited product, i.e. may not sell only one company's product.

In 2002 the Financial Services Authority (2002) published a consultative paper (CP121) on reforming polarisation. The report proposes a reversal of some of the principals implemented under polarisation; hence the term of 'depolarisation'. If the proposals are implemented a new grouping of advisors, multi-tied agents, will be created. These agents will not be independent but will be able to sell products of a number of providers, as opposed to the one provider currently allowed for representatives.

\section{Pressure on capital adequacy}

Pension policies with guaranteed annuity rates were widely sold from the 1970s to the late 1980's. These policies guaranteed the rate at which the cash benefit at maturity can be converted to an annuity (Credit Suisse First Boston, 2002:82). With current interest rates in the region of five percent, these guarantees have an adverse effect on insurers who have to make good the shortfall.

\section{Internet}

In recent research (McKenna, 2002:36) it is estimated that the UK has 20 million Internet users. Of these almost half indicated that they have used it to buy or service a financial product.

As shown by the low level of retail life insurance products sold on an execution basis only (Sandler, 2002:82), the main impact of the Internet on the life insurance market is, however, not in the area of business to consumer interaction, but rather as a tool for intermediaries to improve service to their clients.

Aggregation is a concept where mainly web based distribution platforms gives a user access to the products of more than one product provider. Sandler (2002:82) refers to aggregators of investment products as 'fund supermarkets' and estimates that 50 percent of IFA's have formed relationships with FundsNetwork (set up by US fund manager Fidelity Investments), Cofunds (set up by M\&G, Jupiter, Tradneedle \& Gartmore) or Skandia.

\section{Legacy systems}

Insurance companies adopted computer technology soon after its introduction. Because policies are sold for long terms, it is difficult to decommission systems while policies administered on them are still in force. Sandler (2002:169) estimates that some companies have as many as 17 core information technology (IT) systems. To effectively address the resultant problems, companies need to rationalise the number of different products on their books. Changing of contracts is, however, not an easy process, as policyholders need to agree to the changes. Few companies are thus willing to embark on this route.

Legacy problems have increased recently due to large-scale consolidation in the industry. The effect is that many of the larger insurers have legacy systems causing service difficulties. In the chairman's statement accompanying the interim report, Aviva (2002:3) recognised that integrating many legacy systems is time consuming and that due to this customer service has not been up to standard.

\section{Summary}

The UK has a savings gap of $£ 27$ billion. Government is pressured to find a solution to this economic problem. Regulatory activities focus on reform to simplify the industry. The rationale is that by doing this the consumer will be encouraged to save more. At the same time consumer protection is a major concern due to previous scandals such as the mis-selling of pensions. On the technology front the main factors impacting are the increasing prominence of the Internet and the vast number of legacy systems that need to be maintained.

\section{Deconstruction of the value chain}

Quite a few instances of deconstruction can be observed in various parts of the insurance value chain. In addition, the factors discussed above are likely to lead to future deconstruction that can be used by firms seeking strategic advantage.

\section{Distribution}

Polarisation in the late eighties led to the increased use of IFA's as distributors. Since 1991 it is estimated that the number of individuals in direct sales forces has reduced from 190000 to 20000 (Sandler, 2002:77). 
A move from tied agents to independent advisors was a form of deconstruction. Where the life insurer previously owned the whole value chain via the company sales force, a different organisation (the IFA) now owned part of the distribution function. Although the industry had already started to deconstruct in this manner prior to 1992, polarisation materially increased its pace.

If depolarisation should lead to the increased use of agents, this could be seen as at least a partial reversal of deconstruction, indicating that deconstruction is not permanent. If the impact is the consolidation of IFA's, this fits in with that part of deconstruction theory that holds that the deconstructed distribution organisations will reconstruct in order to gain benefits of scope.

The distribution element of the value chain has, and is likely to continue experiencing various forms of deconstruction, including full, partial and even the reversal of deconstruction.

\section{Product development and risk management}

On the investment product front a view is emerging that the basics of investment is asset allocation. Only once the asset allocation has been satisfied a product type is selected. The product type is selected based on criteria such as cost, tax and regulatory 'wrapper' of the product.

For savings products this thinking brings life policies in direct competition with investments such as unit trusts and other open ended collective investments. A new type of product company offering a generic investment product is predicted. This will result in parts of the industry value chains of insurers, unit trusts and other retail savings product providers being amalgamated into one product provider offering a number of generic investment products 'wrapped' as the buyer requires.

One effect of the increased competition between life and other savings products will be the vast number of choices available to investors and the confusion that this is likely to create. Credit Suisse First Boston (2002:84) predicts that the 'shelf space' of IFA's is limited, as too many options will confuse consumers. This will, in their opinion, lead to a 'flight to quality' to the large financially strong insurers.

No obvious examples of deconstruction for risk products could be found in the market yet. As risk products are becoming commodities where price is the main determinant of the sale, scale requirements will likely lead to changes in the value chain of this product. Although some niche opportunities will be available, most likely in the more affluent end of the market where scale can be achieved with fewer clients, it is predicted that smaller companies in the retail risk market will disappear.

\section{Asset management}

The asset management part of the value chain has not seen a large amount of deconstruction in the traditional sense where a part of the value chains breaks away. This is possibly due to the profitability of the activities. This does not mean that no form of deconstruction has been observed.

The effective market hypothesis holds that because the market prices equities based on all relevant information, an investor should not be able to outperform the market on a consistent basis (Damodaran, 2001:23). The rule of thumb is that only 25 percent of actively managed funds are able to outperform the index at one time (The Motley Fool, 2003:1). This has lead to the increased popularity of index-based (tracking) products. In tracking, the asset manager creates a portfolio that mirrors a major index (e.g. the FTSE 100) usually by buying the underlying investments that comprise the index. The only management needed is to readjust the portfolio when the index changes. Tracker funds currently account for about 30 percent of the UK investment market (Duncan, 2002:26).

ING Barings (2001:58) holds that the value chain of indexers consists mainly of rebalancing, stock lending, forex and custody. All of these activities are highly computer dependent. This means that indexing is highly scaleable. Global companies are thus likely to dominate. Today four global players Barclays, State Street, Bankers Trust and Vanguard dominate this arena (ING Barings, 2001:58).

Credit Suisse First Boston (2002:367) observes that large benefit consultancies are advocating a 'core/satellite' approach. This approach proposes that the bulk of funds are passively invested, with the remainder invested in higher risk vehicles. Frequently private equity and hedge (arbitrage) funds are used for this component.

When comparing this philosophy with that of the traditional actively managed portfolio, one can conclude that the difference indicates deconstruction of the traditional actively managed portfolio. In the actively managed portfolio the elements of tracking, stock picking and arbitrage are mixed in one portfolio. By de-aggregating the components and having separate managers focus on each part, the thinking is that better returns can be achieved.

\section{Operations}

In the operations area the main form of deconstruction appears to be outsourcing of administration to a third party. The logic is that the third party can gather scale, thereby reducing the cost of administration. The outsourcers usually come from a different industry or one formed from a break away from the traditional value chain.

Outsourcing in the operations area is not a new phenomenon. In asset management, outsourcing of certain administration services is common. Myners (2001:74) estimates that 50 percent of asset managers used independent custodians in 1997. This had increased to 71 percent in 1999.

In the life industry a number of factors are impacting on the operations area. The introduction of stakeholder pensions introduced the one percent world. Due to the pressure to achieve lower cost, increased outsourcing activities are predicted. As legislative pressure multiplies, the 
administration of life products is becoming increasingly technical and cumbersome. This is likely to further increase the demand for outsourcing specialist companies.

Due to consolidation in the industry, several companies have a number of 'legacy' systems inherited from companies acquired. To integrate these systems with their own systems requires enormous recourses.

The main advantage of outsourcing is the cost saving that can be achieved by benefits of scale. The main mitigating factors against it seem to be the loss of the ability to differentiate, loss of control and labour opposition. Outsourcing may be limited to the closed book market. In the open book market it seems unlikely that a large switch to outsourcing will occur, as service might be one of the only differentiators left for insurers.

\section{Summary}

It appears that deconstruction is a reality in almost all parts of the value chain. The level of deconstruction, however, differs. Instead of total disintegration, deconstruction is often found to co-exist with the current integrated value chain model. This is an important principle when alternative strategies are explored. The lesson seems to be that an overly simplistic model of the industry will lead to onedimensional solutions, which are likely to lead to failure.

\section{Exploring strategic options for a new entrant}

Evans and Wurster (2000a:60) hold that due to the simpler model that deconstructed businesses follow, less strategic options are available. These options are Scale, Scope or Speed. This means that competition is fiercer but also that monopoly formation is often the logical consequence of the strategies available.

Deconstruction is, however, not an overnight switch but a process wrought with uncertainty. It is seldom complete but rather takes the form of partial unbundling. The challenge will thus be to formulate a strategy that combines those developed for a deconstructed industry with those of a vertically integrated industry.

\section{Distribution}

In the customer aggregation arena a differentiating strategy is most likely needed to be successful. The ability to attract customers is the single most important success factor. To attract customers requires a combination of branding, presence (either physical or perceived) and trust by consumers.

The UK market already has a considerable number of IFA firms and networks. In order to be successful a new entrant will need to build or acquire a presence and a brand. With 11000 IFA firms already in the market, it will be difficult to establish a new brand. One of the lessons that the dot-com era has taught us is the prohibitively high cost of establishing a brand and attracting new customers (Cap Gemini Ernst \& Young, 2001:16). Building a consumer brand will require large investment in an already fragmented market. Even if it this could be achieved, the ease of acquiring an existing IFA must be more cost and time effective.

A second success factor that is needed in the IFA market arises due to the prevalent role that commission plays as the major source of income. Commission is paid by life companies to reward agents for selling products. Commission levels have been deregulated in the UK (Boles, 2002:2).

It seems to be common practice that larger IFA firms, with more muscle due to their ability to switch large amounts of client money, are able to negotiate larger commissions than smaller firms (Boles, 2002:2). This means that scale has an added advantage in this market. Investing in a small firm will thus place a new entrant at an immediate disadvantage relative to bigger competitors.

\section{Product development}

It is predicted that the roles of risk manager, product development and packaging will be combined in most cases and that this is the area where most current life companies will operate. The competition in this market will thus remain high.

Boyd, Walker and Larreche (1998:241) hold that branding is particularly important when it is difficult to measure a product's quality. The quality of life products are by their nature impossible to measure when the product is sold. The brand of the insurer as a large stable organisation is probably the only criterion that the average client has who understands little of capital adequacy and reserving.

In the product market a new entrant will thus have to buy a company with an existing brand as a stable product provider. Credit Suisse First Boston (2002:386) agrees with this sentiment when they state, 'we believe a strong brand is a fundamental requirement for success in the UK life and pensions market'. This will probably mean that a new entrant needs to make an investment in one of the top 20 insurance companies listed in Table 1.

\section{Asset management}

With the majority of retail assets still invested in managed portfolios, there must be a future for active managers. However, once again, for an organisation to be trusted to invest the assets of a product provider and packager it must have a solid track record in investment management.

As previously indicated the indexing element of investment management is a global industry with a few multinationals dominating. The chances of entering this part of the market seem unlikely as it will be difficult to achieve the scale needed to be profitable.

Hedge funds originated in the United States of America (USA) and large competitors from this country are likely to dominate this area of the UK market in future. Again a niche player with access to a distribution network could be an opportune investment. 


\section{Operations}

Competitors in the operations market sells to corporates. The key success factor will likely be the ability to deliver rather than the retail requirements of advertising and brand building. This could be an advantage for a new entrant as marketing can be done in a more focussed way, which could be less expensive.

In the operations area offshore outsourcing, especially to India, is becoming more attractive. Co-operating with an Indian outsourcer can thus be an attractive strategy in this activity.

\section{Summary}

The asset management and operations areas of the value chain could offer some options for new investors. The distribution area, with a large number of competitors, however, seems to offer the most attractive opportunities. By consolidating a number of these competitors, benefits of scope and scale for commission purposes can be achieved.

\section{Conclusion}

The paper demonstrates that the deconstruction of the value chain model can be a useful tool to help a company formulate a strategy for entering a deconstructing industry. The model's main advantage is that it clearly highlights the areas in the value chain where the traditional strategies of differentiation, cost leadership and focus can be applied.

The theory of value chain deconstruction is likely to gain increased popularity. As with most models, a thorough understanding of its strengths and shortcoming is needed. In addition, industry and company specific knowledge is required otherwise the application of the model can have disastrous consequences. Finally, if common sense does not prevail, any model will almost invariably lead to failure.

\section{References}

Association of British Insurers. 2003a. UK Insurance 2002/3 - Key Facts. London: ABI.

Association of British Insurers. 2003b. Current largest 20 long-term UK insurance groups based on UK premiums in 2001. [online] URL: www.abi.org.uk Accessed: 3 January 2003.

Aviva. 2002. Interim Financial Report of Aviva Plc. London: Aviva.

Boles, C. 2002. 'CA wants to see return of MCA to stop buy-up’, Money Marketing, 2 May: 2.

Boyd, H.W., Walker, O.C. \& Lerreche, J. 1998. Marketing management. Boston: Irwin McGraw-Hill.

Bresser, R.K.F., Heuskel, D. \& Nixon, R.D. 2000. 'The deconstruction of integrated value chains: practical and conceptual challenges'. In Bresser, R.K.F., Hitt, M.A., Nixon, R.D. \& Heuskel, D. (Eds.). Winning strategies in a deconstructing world. Chichester: John Wiley and Sons, pp.1-21.

Butler, P. \& Hall, T.W. 1997. 'The revolution in interaction’, McKinsey Quarterly, Issue 1: 4-24.

Cap Gemini Ernst \& Young. 2001. Paths to differentiation 2001 special report on the financial services industry. London: Cap Gemini.

Carbaugh, R.J. 2002. International economics. Cincinnati: South-Western.

Credit Suisse First Boston. 2002. European insurance sector review. February.

Damodaran, A. 2001. Corporate finance. New York: John Wiley and Sons.

Diacon, S.R. \& Carter, R.L. 1992. Success in insurance. Nottingham: John Murray.

Duncan, C. 2002. ' $£$ 2bn merger for Artemis and ABN Amro’, Money Marketing, 13 June: 1.

Ernst \& Young. 2002. The Sandler Report - a commentary. London: Ernst\&Young.

Evans, P. 1998. How deconstruction drives de-averaging. [online] URL: http://www.bcg.com/publications/search_view_perspectives. asp?pubID=241. Accessed: 7 January 2003.

Evans, P. \& Wurster, T.S. 1997. 'Strategy and the new economics of information', Harvard Business Review, 75(5):71-84.

Evans, P.B. \& Wurster, T.S. 2000a. Blown to bits. Boston Massachusetts: Harvard Business School Press.

Evans, P. \& Wurster, T.S. 2000b. 'CLICK.BOOM', Ivey Business Journal, 64(4):35-42.

Financial Services Authority. 2002. Consultation Paper 121 - Reforming polarisation: Making the market work for consumers. January. London: FSA.

Financial Services Authority. 2003. What are CAT standards. [online] URL:

http://www fsa.gov.uk/consumer/financial faqs/ISAs/mn ca thtml. Accessed: 3 January 2003.

Fund Managers' Association. 2001. Fund management survey 2000. February. London: FMA.

Hagel, J. \& Singer, M. 1999a. 'Unbundling the corporation', Harvard Business Review, 77 (2):133-142.

Hagel, J. \& Singer, M. 1999b. Net worth: Shaping markets when customers make the rules. Boston Massachusetts: Harvard Business School Press. 
ING Barings. 2001. Major themes in global fund management. April. London: Charterhouse Securities Ltd.

Marlborough Stirling. 2001. Transforming life and pensions, Issue 3, May:2

McKenna, I. 2002. 'Make tracks for the net', Money Marketing, 2 May:36.

Myners, P. 2001. Institutional investment in the United Kingdom: A review. 6 March. London: HM Treasury.

Oliver, Wyman \& Company. 2002. The future regulation of UK savings and investment - Targeting the savings gap. A study commissioned by the Association of British Insurers. Oliver Wyman \& Company, London.

Porter, M.E. 1985. Competitive advantage. New York: Free Press.

Porter, M.E. 1980. Competitive strategy. New York: Free Press.

Sandler, R. 2002. Medium and long-term retail savings in the UK - a review. July. HMS Treasury, London.

Self, R. 2002. Stakeholder pension scheme. [online] URL: http://www.ciilo.org/factfiles/stakeholder_pension_scemes.p hp. Accessed: 8 January 2003, (members only).

Taylor, D., Seah, C., Cannon, C. \& Stone, M. 2002. 'The future of the UK life and pensions industry', Journal of Pensions Management, 7(4): 351-365.

The Motley Fool. 2003. [Online] URL: http://www.fool.co.uk/ISAs/trackers/trackersvsfunds htm. Accessed: 25 February 2002.

Thompson, A.A. \& Strickland, A.J. 2001. Strategic management concepts and cases. New York: McGraw-Hill.

United States of America. Department of Justice. 2003. The Herfindahl-Hirschman Index. [online] URL: http://www.usdoj.gov/atr/public/testimony/hhi htm.

Accessed: 24 January 2003. 
